\title{
THE ANALYSIS OF THE WORKLOAD OF INPATIENT MEDICAL RECORD DATA UPDATE STAFF USING WORKLOAD INDICATOR OF STAFFING NEED METHOD TO SUPPORT WORK EFFECTIVENESS IN HOSPITAL IN BANDUNG
}

\author{
M Dana Prihadi ${ }^{1)}$, Pri Agung Danarahmanto ${ }^{2)}$, Julia Famor Pratami ${ }^{3)}$ \\ ${ }^{1,2,3)}$ Academy of Medical Recorders and Health Informatics, Bandung, Indonesia \\ Corresponding author: danaprihadi@apikesbandung.ac.id
}

\begin{abstract}
Workload analysis is a human resource planning activity that aims to determine manpower needs in the organization. It means that the number of employees have to be adjusted to the existing workload, so that the employees' work effectiveness can be implemented properly. The population were inpatient medical record data update staff, by using quote sampling technique from the workload of five (5) staffs of inpatient medical record data update. The type of research was descriptive with quantitative approach. The aims of the research were to discover the job descriptions of inpatient medical record data update, to find out the need of human resource in inpatient medical record data update, and to know the work effectiveness of inpatient medical record data update. The data were collected by using interview and documentation techniques. The results of the research were the number of data update files completed in 2019 amounted to 40,910 files out of 43,764 files, with five (5) staffs available. Based on the results of the research on human resource planning in inpatient medical record data update section using Work Indicator of Staffing Need (WISN) method, the result of calculation using the WISN method was 6.24 or 6 in decimal. Based on the calculation, it is advised that the hospital needs to consider adding one more staff in medical record data update section, so that the work effectiveness of the staff can be implemented properly.
\end{abstract}

Keywords: Workload, Data Update, Work Effectiveness, WISN

\section{Introduction}

The Minister of Health Regulation of the Republic of Indonesia Number 3 of 2020 concerning hospital classification and licensing, explains that hospital is health service institution that administers plenary individual health service which provides inpatient, outpatient, and emergency services. (Soeroso, 2003) states that human resource is the main asset of a hospital who becomes the main concern. The statement supports the necessity in planning and calculating the existing manpower in certain units, because the ultimate success of the hospital can be determined by adequate human resources. In addition, according to Minister of Health Regulation Number 269 of 2008 concerning medical record, the medical record is a file containing notes and documents about the identity of patient, medical checkup, medication, treatment, and some other services which have been provided to the patient. (RI, 2008)

The implementation of a complete, accurate, and timely medical record is supported by adequate quality and quantity of the human resources. The quality of the human resource includes skill, knowledge, and education level, whereas quantity covers the number of staff who is sufficient, and in accordance with the existing workload. The number of staff who is in accordance with the workload will affect the level of work efficiency and productivity.(Prihadi, 2020) If the number of staff does not match the existing workload, the work productivity will decrease and it will affect the quality of service in the hospital.

The accumulation of medical record files in medical record unit will lead to delay in several further services, such as delivering files to the poly, and also collecting the medical records themselves after being used. This research was based on the observation made at the hospital in Bandung, by using inpatient medical record data update staff as sample. The average of data updating process was 31 medical record files for 2 hours 7 minutes or 127 minutes, with an average processing time of 4.09 minutes/file. The problem occurred in data update section was the accumulation of medical record files that had not been updated by the staff, and affected to the increase of the workload for each staff.

The research is expected to improve the works in medical record unit. It also can be used to support excellent and quality services for the hospital. Moreover, there are so many new health facilities and hospitals that are built and growing rapidly with good quality of health services.

\section{Research Methods}

The population used in this research are the inpatient medical record data update staffs. The writer used quota sampling, wherein the workload of five (5) staffs of inpatient medical record data update became the samples. Descriptive method with quantitative approach was applied in this research. The process was carried out by calculating the workload of inpatient medical record data update staffs from one staff and another within the same scope. It aimed to notice the comparison of the workload based on the achievement obtained in a day, without seek the differences between one staff and another. (Hasibuan, 2003) The data collection 
technique in the research used interview technique to the head of the sub-section of inpatient medical record installation, to obtain information containing the workload of the staff of data updating, and also by conducting the documentation studies through the data sources obtained from the interviews. The data processed was the data in a year, namely in 2019.

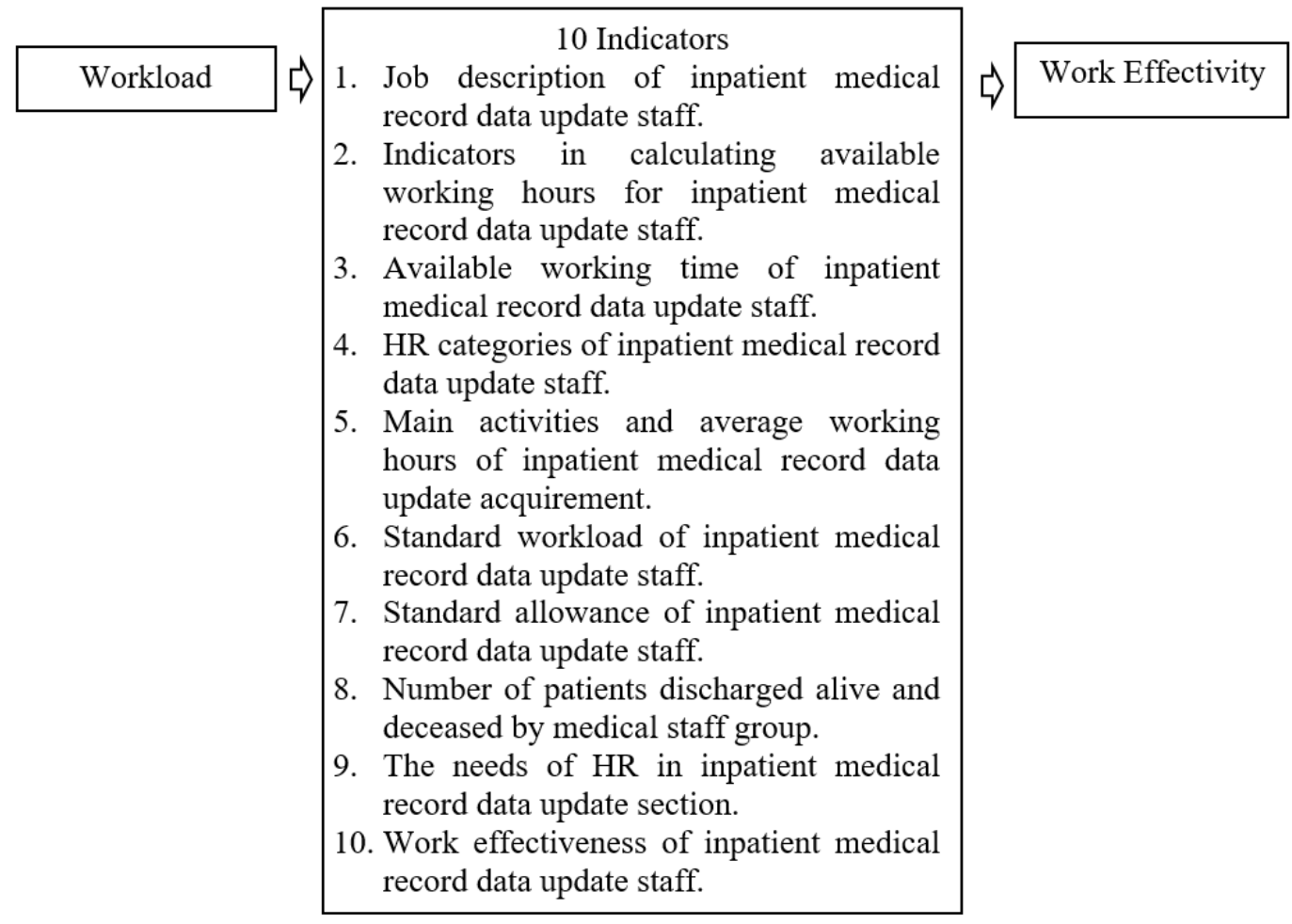

Figure 1. Framework

\section{Result and Discusssion}

Table 1. Job Description of Inpatient Medical Record Data Update Staff

\begin{aligned} \hline 1. & Receiving files from analysis staff. \\ \hline 2. & Calculating the number of received files. \\ \hline 3. & Calling the billing number in the entry-exit summary form sheet in computer data. \\ \hline 4. & $\begin{array}{l}\text { Checking the suitability of the data, starting from patient's name, readmission and discharge date, } \\ \text { gender, room, address, diagnosis, treatment, and the chief physician. }\end{array} \\$\hline 5. & Completing the diagnostic code, treatment, and chief physician that has not been indexed. \\ \hline 6. & Correcting if there are errors in patient's identity, disease index, treatment index, and doctor index. \\ \hline 7. & $\begin{array}{l}\text { Grouping the updated data files according to the functional medical unit/medical staff group that } \\ \text { treats the patient. }\end{array} \\$\hline 8. & $\begin{array}{l}\text { Writing medical record file on the medical record file submission form in accordance with the } \\ \text { functional medical unit/medical staff group. }\end{array} \\$\hline 9. & Submitting the medical record file to the file storage staff. \end{aligned}
Source: Writer's Research Result

Table 2 shows the job descriptions which have to be completed by the staff, starting from medical record files entry to the inpatient medical record data update section to the medical record file is saved to the inpatient medical record file storage. In general, the jobs of inpatient medical record data update staff are in accordance with the existing procedures, hence the data update processing is implemented properly.

There is also the calculation of human resource needs of inpatient medical record data update staff that has been counted based on Workload Indicator of Staffing Need (WISN). As the result of the writer's research, it can be known that the medical record staff's working hours is:
Monday-Thursday
: 07.00-15.30 WIB
Break
Friday
: 07.30-16.00 WIB
Break
: 11.30-13.00 WIB 
Table 2. Determining Indicators in Calculating Available Working Time for Inpatient Medical Record Data Update Staff

\begin{tabular}{cl}
\hline Code & \multicolumn{1}{c}{ Indicator } \\
\hline A & $\begin{array}{l}\text { Working days, according to hospital regulation are five (5) working days a week, in other words, } \\
\text { in a year there are 260 working days (5 x } 52 \text { weeks). }\end{array}$ \\
\hline B & Annual leave, according to hospital regulation is 12 working days in a year. \\
\hline C & $\begin{array}{l}\text { Education and research, hospital does not provide education and research for medical record staff } \\
\text { yet. }\end{array}$ \\
\hline D & $\begin{array}{l}\text { Public holidays, according to joint decision signed by Minister of Religion Luqman Hakim } \\
\text { Saifuddin, Minister of Manpower Harif Dhakiri, and Minister of State Apparatus Utilization and }\end{array}$ \\
& $\begin{array}{l}\text { Bureaucratic Reform (PANRB) Syafruddin. In the joint decision, it is stated that the number of } \\
\text { public holidays in 2019 is 20 days with a statement of 16 days of public holidays and } 4 \text { days of } \\
\text { collective leave for the holidays. }\end{array}$ \\
\hline E & $\begin{array}{l}\text { Absence from work, according to the data on average absence from work in } 2019 \text { is } 5 \text { working } \\
\text { days. }\end{array}$ \\
\hline F & Working hours, according to hospital regulation, in 1 working day is 7.5 hours. \\
\hline
\end{tabular}
Source: Writer's Research Result

The Calculation of Available Working Time is $=(\mathrm{A}-(\mathrm{B}+\mathrm{C}+\mathrm{D}+\mathrm{E})) \times \mathrm{F}$. The formula and description of calculation of available working days and available working time of inpatient medical record data update staff is:

$$
\begin{aligned}
\text { Available Working Days } & =\{\mathrm{A}-(\mathrm{B}+\mathrm{C}+\mathrm{D}+\mathrm{E})\} \\
& =\{260-(12+0+20+5)\} \\
& =223 \text { days/year } \\
\text { Available Working Time } & =\{\mathrm{A}-(\mathrm{B}+\mathrm{C}+\mathrm{D}+\mathrm{E})\} \times \mathrm{F} \\
& =\{260-(12+0+20+5)\} \times 7.5 \\
& =\{260-37\} \times 7.5 \\
& =1672.5 \text { hours/year } \\
& =100,350 \text { minutes/year }
\end{aligned}
$$

Table 3. Available Working Time of Inpatient Medical Record Update Staff

\begin{tabular}{clrc}
\hline Code & \multicolumn{1}{c}{ Indicators } & Number & Description of Time \\
\hline A & Working Days & 260 & Days/Year \\
\hline B & Annual Leave & 12 & Days/Year \\
\hline C & Training Education & 0 & Days/Year \\
\hline D & Public Holidays & 20 & Days/Year \\
\hline E & Absence from Work & 5 & Days/Year \\
\hline F & Working Time & 7.5 & Hours/Day \\
\hline Available Working Days & 223 & Days/Year \\
\hline & & 1672.5 & Hours/Day \\
Available Working Time & 100,350 & Minutes/Year
\end{tabular}

Source: Writer's Research Result

Found on the results of the calculations in Table 3, it can be seen that the available working time for inpatient medical record data update staff is 1672.5 hours/year or 100,350 minutes/year.

Table 4. HR Categories and Work Units of Inpatient Medical Record Update Staff

\begin{tabular}{llc}
\hline \multicolumn{1}{c}{ Work Units } & \multicolumn{1}{c}{ HR Categories } & Number \\
\hline Inpatient Medical Record Data Update & 3-Year Diploma in Medical Record & 3 \\
\hline Inpatient Medical Record Data Update & 4-Year Diploma in Medical Record & 2 \\
\hline Source: Writer's Research Result & &
\end{tabular}

Table 4 indicates that the competency of graduates of inpatient medical record data update staff consists of three (3) 3-year Diploma in Medical Record staffs, and two (2) 4-year Diploma in Medical Record staffs. 
Table 5. Main Activities and Average Working Hours of Inpatient Medical Record Data Update Acquirement in 2019

\begin{tabular}{cccccc}
\hline No & Staff's Name & Per & $\begin{array}{c}\text { Per } \\
\text { Month }\end{array}$ & $\begin{array}{c}\text { Per } \\
\text { Day }\end{array}$ & $\begin{array}{c}\text { A Medical Record File } \\
\text { Processing Time }\end{array}$ \\
\hline 1. & P.A & 7560 & 630 & 31 & 14.52 minutes \\
\hline 2. & P.B & 9273 & 773 & 39 & 11.54 minutes \\
\hline 3. & P.C & 6267 & 522 & 26 & 17.31 minutes \\
\hline 4. & P.D & 7878 & 657 & 33 & 13.64 minutes \\
\hline 5. & P.E & 7732 & 644 & 35 & 12.86 minutes \\
\hline \multicolumn{7}{c}{ Total minutes per medical record file } \\
\hline
\end{tabular}

\section{Source: Writer's Research Result}

Based on Table 5, the average time per main activity of inpatient medical record data update staff is 13.97 minutes. Therefore, the calculation of the standard workload of the inpatient medical record data update staff is:

$$
\begin{aligned}
\text { Standard Workload } & =\frac{\text { Available Working Time }}{\text { Average Time Per Main Activity }} \\
\text { Standard Workload } & =\frac{100,350 \frac{\text { minutes }}{\text { year }}}{13.97 \text { minutes }} \\
& =7183.24 \text { minutes } / \text { year }
\end{aligned}
$$

Table 6. Standard Workload of Inpatient Medical Record Data Update Staff

\begin{tabular}{lccc}
\hline \multicolumn{1}{c}{ Work Unit } & $\begin{array}{c}\text { Average Time Per } \\
\text { Main Activity }\end{array}$ & $\begin{array}{c}\text { Available Working } \\
\text { Time }\end{array}$ & Standard Workload \\
\hline $\begin{array}{l}\text { Inpatient Medical Record } \\
\text { Data Update }\end{array}$ & 13.97 minutes & 100,350 minutes/year & 7183.24 minutes/year \\
\hline
\end{tabular}

Source: Writer's Research Result

Table 6 shows that standard workload of inpatient medical record data update staff is 7183.24 minutes/year. In addition, there is also the calculation in organizing the standard allowance of inpatient medical record data update staff. To discover the standard allowance, it is quite important to do some activities unrelated to the main activities. The activities can be done, whereas the inpatient medical record data update staff have one hour or 60 minutes standard allowance time every day, and also an additional of 30 minutes in break time every Friday. In other words, each of the staff can have 5.5 hours or 330 minutes in a week, and if it is accumulated in a year, thus 5.5 hours/week x 52 weeks/year $=286$ hours/year.

$$
\begin{aligned}
\text { Standard Allowance } & =\frac{\text { Average Per Allowance Factor }}{\text { Available Working Time }} \\
\text { Standard Allowance } & =\frac{286 \text { Hours } / \text { Year }}{1672.5 \text { Hours } / \text { Year }} \\
& =0.17 \text { Hours } / \text { Year }
\end{aligned}
$$

Table 7. Standard Allowance of Inpatient Medical Record Data Update Staff

\begin{tabular}{cccccc}
\hline $\begin{array}{c}\text { Allowance } \\
\text { Factor }\end{array}$ & Frequency & Time & Number & $\begin{array}{c}\text { Available } \\
\text { Working Time }\end{array}$ & $\begin{array}{c}\text { Standard } \\
\text { Allowance }\end{array}$ \\
\hline Break & 260 days & $\begin{array}{c}\text { 1 hour }(+30 \\
\text { minutes in a week) }\end{array}$ & 286 hours & $\begin{array}{c}1672.5 \\
\text { hours/year }\end{array}$ & 0.17 hours/year \\
\hline
\end{tabular}

\section{Source: Writer's Research Result}

The result of calculation in Table 7 states that standard allowance of inpatient medical record data update staff is 0.17 hours/year. The calculation of the human resource needs for inpatient medical record data update staff can be obtained from available working time, standard workload, and standard allowance that have been conducted previously. It is also included the main activities which are obtained in accordance to the number of patients discharged alive and deceased stated by inpatient medical staff group in 2019 . 
Table 8. Number of Patients Discharged Alive and Deceased by Medical Staff Group in 2019

\begin{tabular}{llrrrrr}
\hline No. & $\begin{array}{c}\text { Functional } \\
\text { Implementation Units }\end{array}$ & $\begin{array}{c}\text { Discharged } \\
\text { Alive }\end{array}$ & $\begin{array}{c}\text { Deceased } \\
<24 \text { Hours }\end{array}$ & $\begin{array}{c}\text { Deceased } \\
>\text { 24 Hours }\end{array}$ & $\begin{array}{c}\text { Total Deceased } \\
\text { Patients }\end{array}$ & Total \\
\hline 1. & Internist & 10156 & 555 & 813 & 1368 & 11524 \\
\hline 2. & Pediatrician & 9127 & 383 & 526 & 909 & 10036 \\
\hline 3. & General Surgeon & 7048 & 168 & 411 & 579 & 7627 \\
\hline 4. & Midwifery & 4019 & 15 & 17 & 32 & 4051 \\
\hline 5. & Obstetrician & 3092 & 45 & 92 & 137 & 3229 \\
\hline 6. & Neurologist & 2224 & 236 & 266 & 502 & 2726 \\
\hline 7. & Orthopedist & 1662 & 12 & 41 & 53 & 1715 \\
\hline 8. & Neurosurgeon & 1289 & 45 & 110 & 155 & 1444 \\
\hline 9. & ENT & 1280 & 21 & 23 & 44 & 1324 \\
\hline 10. & Oral Surgeon & 1192 & 5 & 7 & 12 & 1204 \\
\hline 11. & Urological Surgeon & 1159 & 18 & 34 & 52 & 1211 \\
\hline 12. & Nuclear Radiologist & 601 & 1 & 0 & 0 & 602 \\
\hline 13. & Radiotherapy & 474 & 0 & 0 & 374 \\
\hline 14. & Psychiatry & 214 & 0 & 3 & 8 & 217 \\
\hline 15. & Dermatologist & and & 137 & 2 & 6 & 145 \\
\hline TOTAL & Gynecologist & 43674 & 1506 & 2349 & 3855 & 47529 \\
\hline
\end{tabular}

Source: Management of Inpatient Medical Record

HR Needs $=\frac{\text { Main Activities Quantity }}{\text { Standard Workload }}+$ Standard Allowance

HR Needs $=\frac{43674}{7183.24}+0,17$

HR Needs $=6.24$

Table 9. The Result of Calculation of HR Needs In Inpatient Medical Record Data Update Section

\begin{tabular}{lccc}
\hline \multicolumn{1}{c}{ HR Criteria } & Needs & Available & Description \\
\hline $\begin{array}{l}\text { Inpatient Medical Record Data } \\
\text { Update Staff }\end{array}$ & 6.24 & 5 staffs & Need to be added one (1) person. \\
\hline
\end{tabular}

Source: Writer's Research Result

The result of calculation in the Table 10 shows that the human resource needs for inpatient medical record data update staff is 6.24 or 6 persons in decimal. It is necessary to add one more person as a staff, regarding the available staffs are only five (5) persons.

Table 10. Work Effectiveness Indicators of Data Update Staff

\begin{tabular}{clc}
\hline No. & \multicolumn{1}{c}{ Indicators } & Category \\
\hline 1. & Quantity & Poor \\
\hline 2. & Quality & Good \\
\hline 3. & Time Utilization & Good \\
\hline
\end{tabular}

Source: Writer's Research Result

Based on Table 11, it can be seen that the quantity of processing inpatient medical record data update can be said to be less than optimal. It happens because the result of calculation in human resource needs of inpatient medical record data update staff should be six (6) persons. Meanwhile, the available staffs in inpatient medical record data update section are only five (5) persons, and surely affect to work acquirement which is not achieved by inpatient medical record data update staff.

However, the quality of inpatient medical record data update processing is in a good level. It can be known from the result of the II fieldwork practice, the staffs of inpatient medical record data update are always careful in entering medical record file into the data base. Other than that, the staffs always count the files which enter and leave the analysis and data update section, before the files are saved into the inpatient medical record file storage area.

In addition, the time utilization of inpatient medical record data update staff is quite good. It is indicated from the number of files updated by the inpatient medical record data update staffs in 2019 which amounts to 40.910 files out of 43.764 patients discharged alive and deceased. 


\section{Conclusion}

Based on the results in the research and discussion, it can be concluded hinge on Workload Indicator of Staffing Need (WISN) in calculating the workload of the inpatient medical record data update staff, it is known that the available working time of the inpatient medical record data update staff is $16,725.5$ hours/year or 100.350 minutes/year for five (5) staffs. The average time per activity for inpatient medical record data update staff is 13.97 minutes in processing one file, which results standard workload in the amount of 7,183.24 minutes/year. In addition, the standard allowance of inpatient medical record data update staff is 0.17 hours/year.

It is necessary to know that the number of available inpatient medical record data update staff have to be six (6) persons. In terms of the work effectiveness of inpatient medical record data update staff, the quantity inpatient medical record data update processing is less because based on the result of the calculation using Workload Indicator of Staffing Need (WISN) the number of available staffs have to be added by one person. It caused the data update acquirement in 2019 was not optimal. Hence, the quality of data update processing is good because the staffs are always careful in processing inpatient medical record data update. In time utilization, the staffs also do good job because the number of completed data update are 40,910 files out of 43,764 patients discharged alive and deceased. Nevertheless, it will be better if the data update staffs do more optimal in time utilization, considering there are still staffs who are late for work and use working time for having breakfast in inpatient medical record data update room.

Regarding to the results and conclusions of the research, the writer suggests that there should be an additional one (1) person in inpatient medical record data update staff. It aims to optimize the work performance in the hospital. The hospital also should provide additional education and training for medical record staff, with the intention of upgrading medical record science for the staffs since the knowledge will always grow and develop. It is also mentioned in Constitution Number 13 of 2003 concerning employment, employees have right to develop their work competencies. It should be better if the hospital provides some kind of rewards and punishments for medical record staff, especially in inpatient medical record data update unit with (Soeroso, 2003) (Ramawati, 2015)the intention of creating better work effectiveness.

\section{References}

Depkes RI 2004. Keputusan Menteri Kesehatan Republik Indonesia Nomor : 81/MENKES/SK/I/2004, Pedoman penyusunan Perencanaan Sumber Daya Manusia Kesehatan Di tngkat Propinsi, Kabupaten/Kota Serta Rumah Saki, Jakarta.

Depkes RI 2008, Peraturan Menteri Kesehatan Nomor. 269/MENKES/III/2008 Tentang Rekam Medis, Dinas Kesehatan.

Depkes RI 2013. Peraturan Menteri Kesehatan Nomor 71 Tentang Pelayanan Kesehatan Pada Jaminan Kesehatan Nasional.

Depkes RI 2020. Peraturan Menteri Kesehatan Nomor 3 Tentang Klasifikasi dan

Perizinan Rumah Sakit. Jakarta

Hasibuan, Malayu S.P. 2003. Managemen Sumber Daya Manusia Jakarta: PT Bumi Aksar.

Prihadi, M. D., \& Yuliani, J. (2020). Analisis Kinerja Petugas Rawat Jalan Guna Menunjang Mutu Pelayanan di Rumah Sakit Mitra Anugrah Lestari Cimahi [Performace Analiysis of Outpatien Officers to Support Quality of Services at Mitra Anugrah Lestari Cimahi Hospital]. Jurnal Bina Administrasi, 7(1), 45-55.

Rahmawati E, 2015. Analisis Kebutuan Jumlah Tenaga Kerja Berdasarkan Beban Kerja Di Unit Rekam Medis Rumah Sakit Umum Assalam Gemoong.

Soeroso, Santoso, Dr. 2003. Manajemen Sumberdaya Manusia Di Ruma Sakit, Jakarta : ECG. 